\title{
Anmeldelse: Europas krise
}

\section{Af Uffe Østergård}

Næsten samtidig med udgaven på engelsk er den bulgarske sociolog og filosof Ivan Krastevs (f. 1965) nøgterne diagnose af EU's kvaler udkommet på dansk på Informations Forlag. Det er godt set af både avis og forlag. Bogen er skrevet før Macrons sejr ved præsidentvalget i Frankrig i foråret 2017 og er dybt pessimistisk på EU's vegne.

Ivan Krastev: Efter Europa, Informations forlag 2017.

Krastevs pessimisme skyldes at han ser på EU fra et østeuropæisk perspektiv. Modsat vesteuropæerne har østeuropæerne nemlig oplevet sammenbruddet for et tilsyneladende solidt politisk system. Ifølge Ivan Krastev, der af sit danske forlag præsenteres som vor tids Alexis de Tocqueville (1805-59), har europæere i Øst og Vest helt forskellige erfaringer.

På den ene side har befolkningerne i Øst oplevet tilsyneladende stærke regimer gå i opløsning indefra, på den anden side så man i Vest med glæde kommunismens undergang som et bevis på demokratiets og den liberale markedsøkonomis styrke.

Vesteuropæerne forstod aldrig, at kommunismens kollaps ikke kun var en befrielse fra undertrykkelse, men en omvæltning af samfundets orden, der indebar total omkalfatring af karriereog pensionsforventninger for den del af

Uffe Østergård er historiker og debattør med speciale i europæisk identitetshistorie. Han er Jean Monnet professor i europæisk civilisation og integration ved Aarhus Universitet og professor i europæisk og dansk historie ved Copenhagen Business School. 
befolkningen, der var over fyrre. Frigørelsen fra kommunismen indebar nok en befrielse, men var også en traumatisk oplevelse af en verdens undergang. Det forklarer ifølge Krastev mange af forskellene på, hvordan verden opfattes i Warszawa, Budapest, Bukarest og Sofia på den ene side og i Paris, Berlin og København på den anden.

Samtidig er de hidtil privilegerede i Vest bange for at miste fordele til arbejdsivrige østeuropæere - samt kriminelle, der som altid har været de første til at udnytte de åbne grænser. I Danmark har problemerne med arbejdskraftens frie bevægelighed ført til en forståelse mellem Dansk Folkeparti og Socialdemokraterne.

Populister, nationalkonservative og mange socialdemokrater taler til flertallets behov for beskyttelse mod indvandrere og flygtninge og gør EU til modstanderen, som vi har set $\mathrm{i}$ valg efter valg, senest i det traditionelt EU-begejstrede Italien. Det europæiske projekt bygger på beskyttelse af mindretal, men den dominerende politiske bevægelse i Europa er nu blevet beskyttelsen af flertallet mod mindretallene.

\section{Øget nationalisme}

Krastev er ikke en konservativ tænker, som vil forsvare sit land mod EU, eller en venstreorienteret modstander af EU som kapitalens projekt. Han er principielt tilhænger af Europa, men hans analyse er, at den politiske, sociale og økonomiske udvikling er ved at ødelægge EU.

Krastev nævner mærkeligt nok ikke kultur og identitet i opregningen af krisefaktorerne i sin korte bog. Men det ville bekræfte hans analyse.

Der er mange paradokser i europæisk samarbejde, men et af de største er, at nationalstaterne reelt er blevet styrkede samtidig med, at vælgerne frygter, at deres nationale suverænitet er ved at forsvinde. Denne fejlagtige tro bliver ikke rigtigere af, at mange politikere tror det samme.

Det europæiske samarbejde har til overraskelse for både modstandere og tilhængere styrket nationalstaterne og nationalismen, uden at det indtil videre har ført til en bedre forståelse mellem befolkningerne. Gamle nationale stereotyper om 'tyskerne' er mere populære end nogen sinde i Grækenland, Italien og Spanien samt i Storbritannien, hvor stereotyperne nu har været der hele tiden, i hvert fald i de populistiske boulevardblade.

Men heller ikke tyskerne, finnerne eller nederlænderne holder sig tilbage med generaliserende udtalelser om 'dovne og ansvarsløse sydeuropæere', selv om deres arbejdstid er væsentligt længere og ferierne kortere end i Nordeuropa. Den folkelige forståelse for det europæiske samarbejde er ikke vokset i takt med dets succes. Tværtimod er deltagelsen i valgene til Europa-Parlamentet faldet st $\varnothing t$ siden indførelsen af det direkte valg i 1979 og omvendt proportionalt med dets indflydelse og seriøsitet.

Det skyldes ifølge Krastev, at vælgerne føler sig snydt af den teknokratiske og elitære samarbejdsmåde, som forbindes med samarbejdets grå eminence Jean Monnet (1888-1979). Både når metoden virker og når den ikke gør. 
Forsøget på at rette op på det med en egentlig forfatning for EU led ynkeligt skibbrud i 2005. Og magtkoncentrationen i euro-gruppen og det Europæiske Råd af statsledere gør det ikke bedre. Heller ikke de nationale parlamenter har følt sig tiltalt af forslagene om at blive mere involveret i udarbejdelsen af den detaljerede lovgivning i de titusindvis af sider i det såkaldte 'acquis communautaire', som regulerer det fælles marked.

Især er nationalismen vokset efter den store udvidelse i 2004. Det skyldtes i første omgang finanskrisen, men er også udtryk for forskellen mellem Øst og Vest. Herunder at kommunismens ødelæggende virkninger på mentalitet og politisk kultur var langt større, end vi gjorde os klart i udvidelsens eufori, som Ivan Krastev fremhæver i sin skarpsindige analyse.

\section{Første Verdenskrig fortsætter}

Historisk kan den geopolitiske situation formuleres som, at Anden Verdenskrig nok er forbi, men at den Første Verdenskrig, som den anden var fortsættelsen af, ikke er slut.

Det gælder i Mellemøsten med borgerkrigene i Irak, Syrien og Tyrkiets anti-kurdiske politik. Men gælder også Ukraine og Sydøsteuropa. Det ved man bare ikke i Bruxelles. EU synes aldeles uforberedt på at skulle forholde sig til en verden, hvor geopolitik er kommet tilbage, og staterne igen er optaget af grænser og territorium som før EU.

Styrkelse af national stolthed er blevet et større politisk succeskriterium end økonomisk fremgang på Vestbal- kan og i Østeuropa. EU har uden rigtigt at ville det overtaget ansvaret for Balkan med løfte om medlemskab og et par protektorater i Bosnien og Kosovo, der ikke fungerer. Indtil videre med det resultat, at EU's manglende evne og vilje til at tænke og agere som geopolitisk spiller er afsløret.

Det samarbejde, Romtraktaten lagde grunden til i 1950'erne, er i større vanskeligheder end nogen sinde, men det blev stort set ikke nævnt i festtalerne i 60-året for Romtraktaten i sommeren 2017. Hykleri har EF og EU altid været god til og har kunnet slippe afsted med, indtil strømmene af flygtninge og immigranter afslørede, at Unionen ikke kan beskytte sine grænser.

Det er svært at forstå, at det kun er 13 år siden, at den britiske politiske iagttager Mark Leonard (f. 1974) udsendte en bog med den optimistiske titel, Why Europe will run the $21^{\text {st }}$ Century, hvor han forudsagde, at det civiliserede EU ville dominere den globale verden på bekostning af primitive magter som USA og Kina. Men det er det, og han takkes i Krastevs forord som nær diskussionspartner.

\section{Perhapsburg}

Man bliver klogere på dagens EU, der halter fra krise til krise og holder vejret mellem valg efter valg, ved at læse denne i omfang lille bog. Og så får man oven i købet en betinget optimistisk analyse af Europas fremtid under den raffinerede overskrift 'Perhapsburg'.

Med denne lidt indforståede betegnelse henviser Krastev til læren af det 
multinationale Habsburgske imperium i Centraleuropa. Det vigtige er ikke at forstå, hvorfor det blev opløst efter nederlaget i Første Verdenskrig november 1918, men hvorfor det overlevede kriserne i 1804, 1848 eller 1867. At Østrig-Ungarn overlevede nederlaget til Preussen i 1866 svarer til, at den flersprogede dansk-tyske helstat havde overlevet nederlaget i 1864 . Det havde ikke været godt for det etnisk homogene demokrati, vi opfatter som dansk, men havde været bedre for en civiliseret og flersproget retsstat.

En sådan fremtid for EU sætter Krastev sin lid til ved at berette om de tre personer, der reddede demokratiet i Spanien fra et militærkup 23. februar 1981, tre år efter vedtagelsen af en demokratisk forfatning.

De tre demokratiets helte var den tidligere frankistiske politiker Adolfo Suárez (1932-2014), kommunisten
Santiago Carillo (1915-2012) og general Gutiérrez Mellado (1912-95), der havde kæmpet i borgerkrigen på Francos side 1936-39 og gjort karriere under hans styre.

De tre bød kupmagerne fra guardia civil trods, da de trængte ind $\mathrm{i}$ parlamentet. De tre meget forskellige medlemmer af parlamentet nægtede at lægge sig på gulvet ligesom de andre medlemmer, selv om kupmagerne skød på dem. Deres fysiske mod, der blev sendt på tv, dømte kuppet til at mislykkes og reddede det unge spanske demokrati.

Det er sådanne modige og samtidig kompromisberedte skikkelser med civilcourage, Krastev håber kan redde EU fra den nationalistiske populisme.

Men optimist er han ikke. 